\title{
Socioeconomic factors and work disability: Clues to managing chronic pain disorders
}

\author{
Robert W Teasell MD FRCPC, Hillel M Finestone MD FRCPC
}

\begin{abstract}
RW Teasell, HM Finestone.
Socioeconomic factors and work disability: Clues to managing chronic pain disorders.

Pain Res Manage 1999;4(2):89-92.

Disability is a multifactorial phenomena in chronic pain disorders, as it is for other painful and nonpainful medical conditions. Socioeconomic factors are important determinants of disability, although this aspect of disability in chronic pain disorders is often ignored. Lower socioeconomic status has been shown to be associated with an increase in the frequency and severity of disability, and the rate of progression to disability in patients with chronic pain. Work disability in lower socioeconomic groups is associated with issues of physical work demands and work flexibility (ie, the ability to control the pace of work, take unscheduled breaks or engage in modified work). Workplace interventions, particularly in the subacute phase, that are geared to workers' limitations offer the best opportunity to reduce the current burden of disability. Where such work modifications are not available, disability will be problematic.
\end{abstract}

Key Words: Chronic pain; Disability; Socioeconomic; Work Modifications

\section{Facteurs socio-économiques et incapacité au travail : indices pour la prise en charge des troubles douloureux chroniques}

RÉSUMÉ : L'incapacité est un phénomène multifactoriel dans les troubles douloureux chroniques, et il en est de même pour les autres pathologies douloureuses et non douloureuses. Les facteurs socio-économiques sont des déterminants importants de l'incapacité, bien que cet aspect de l'incapacité dans les troubles douloureux chroniques soit souvent ignoré. Il a été démontré qu'un niveau socio-économique plus faible est associé à une augmentation de la fréquence et de la sévérité de l'incapacité et au taux de progression vers l'incapacité chez les patients atteints d'une douleur chronique. L'incapacité au travail dans les groupes socio-économiques défavorisés est associée à des questions concernant l'allégement du travail physique ou la flexibilité du travail (c'est-à-dire, pouvoir contrôler la cadence de travail, faire des pauses non planifiées ou modifier les tâches). Les interventions en milieu de travail, en particulier dans la phase subaiguë, qui s'adressent aux limites des travailleurs offrent la meilleure solution pour réduire le fardeau actuel de l'incapacité. Dans les endroits où ces modifications ne peuvent être réalisées, l'incapacité sera problématique.
$\mathrm{D}$ isability is a multifactorial phenomenon, a fact often forgotten or misused in the determination of the disability associated with chronically painful conditions. Although it is frequently assumed by physicians that health factors, such as the particular medical diagnosis, have the greatest effect on work disability, social scientists have long argued that the strongest correlates of work status of individuals with chronic disease are age, education, occupation and job status in the labour force (1-5). This relationship between socioeco- nomic factors and the likelihood of work disability is recognized as intuitively obvious with disorders such as spinal cord injuries, traumatic brain injuries, stroke and rheumatoid arthritis (RA), where pathophysiological correlates are readily available. However, with chronic pain disorders, where clearly defined pathophysiological findings are harder to see, the relationship between socioeconomic factors and the likelihood of work disability is often not appreciated. As such it would be useful to explore the relationship between work dis- 
ability and socioeconomic factors and determine whether chronic pain disorders are different from the other aforementioned medical disorders.

\section{STROKE AND SPINAL CORD INJURIES}

Among stroke patients, the rate of return to work for those working at the time of their stroke is as low as $17 \%$ (6). The majority of those who return to work do so with reduced hours or part-time work $(7,8)$. Patients who have higher educational levels, white collar positions and less demanding jobs were more likely to return to work after a stroke than those with little education and blue collar positions (9-12). Those workers more likely to successfully return to work had more work autonomy, or fellow employees and employers were more likely to accommodate these individuals at work (9). Similarly, Krause and Anson (13) in a recent study of 362 respondents with spinal cord injuries found that $25 \%$ were working and only $12 \%$ had returned to their pre-injury employment. Employment at the time of the study was only 9\% for those with less than a high school education but 52\% for those with 16 years of education or more $(\mathrm{P}<0.001)$. Patients who had more than 16 years of education were more likely to return to their pre-injury job (41\%) than those who had less than 12 years of education $(11 \%)(\mathrm{P}<0.01)$ (13).

\section{RHEAUMATOID ARTHRITIS}

Among RA patients, Reisine et al (14) found that work autonomy (the ability to pace) and the physical nature of the job were more important than disease severity in determining work disability. Reisine et al (15) later pointed out that the complexity of the work itself, the desire to remain employed and reduced work hours influenced work disability among rheumatoid arthritis patients. Yelin et al (1) studied 180 patients with rheumatoid arthritis. The probability of work loss was great even for those patients with mild disease of short duration. Again, there was a significant effect noted for premorbid income and marital status. Individuals who were self-employed, had high work autonomy, were able to determine their own work pace and had flexibility regarding work activities had lower levels of disability (1). Yelin et al (1) noted,

\footnotetext{
"rheumatoid arthritis is fairly typical among chronic diseases in subjecting the patient to periods of flare-up and remission for which control over the pace and activities of work could be crucial. Workers need to be able to hold back on work during flare-ups, perhaps taking as much time-off as their accumulated vacation and sick leave, or as little as the time required to visit a physician. In a recent survey among a random sample of American workers, in fact, $16 \%$ indicated that inflexibility of work time presented them with serious problems in personal and health matters".
}

\section{CHRONIC PAIN DISORDERS}

Chronic pain disability is influenced by factors that are similar to those disabling conditions just reviewed. Leavitt (16) studied 1580 patients who presented with low back pain who were working at the time of injury. Individuals in occupations involving heavy physical exertion were disabled for the longest period of time, whereas those involved in jobs requiring no physical exertion were disabled for the shortest time. The importance of the physical demands of the job was borne out by a study conducted by Yelin et al (17), who reviewed data regarding 3100 adults with limitations in activities and chronic disease who responded to the 1978 Social Security Administration Survey of Disabled and Non-Disabled Adults. The authors looked at a variety of factors that correlated with work disability. They note,

\section{"The nature of the work itself had the most profound impact on whether the musculoskeletal disease patients stopped working after onset of the condition. Persons in white-collar occupations had far lower disability rates than others; persons in service occupations had far higher rates. Self-employment, too, reduced the probability of lost work. Among all the work variables, the interaction of the demands of the job and the limitations one experienced in performing them had the strongest effect among disability status".}

The same authors noted that work disability did not correlate well with the severity of symptoms of low back pain (as with the previously discussed RA) but did with the demands of the workplace. This suggested that chronic pain tends to produce work disability when the job is physically demanding and the workplace inflexible. Disability resulted more from the interaction of pain and the physical demands of the job rather than solely the severity of the pain itself or the individual's work attitude. Disability is, therefore, in part determined by the ability of the individual to find alternative work or by the willingness and ability of the workplace to accommodate work restrictions (18).

Lower socioeconomic status has been shown to be associated with an increase in the frequency and severity of disability, and the rate of progression to disability in patients with musculoskeletal disorders, including arthritic conditions (19-22). Badley and Ibanez (23) note that several population studies have reported an increased frequency of chronic musculoskeletal disorders in individuals with lower levels of education and lower incomes (24-26). Pincus et al (26) noted that patients with musculoskeletal disorders who are of lower socioeconomic status (less than 12 years of formal education) have an increased risk of disability compared with individuals of higher socioeconomic status. Low back pain is more common among those in lower socioeconomic groups than among those in upper socioeconomic groups $(27,28)$, a trend that is likely partially attributable to the more physically demanding and inflexible work performed by blue collar workers (29). 
Badley and Ibanez (23) bring all of the concepts together when they point out that those of lower socioeconomic status report more chronic health conditions and are more likely to report lower functional status, greater limitation of daily activities and less good health $(30,31)$. In a cross-sectional survey of Canadian households (over 16 years), Badley and Ibanez (23) found that disability was independently associated with increasing age, not being married, fewer years of schooling, lower income and not being employed. These risk factors were similar for both musculoskeletal and nonmusculoskeletal causes of disability. Badley and Ibanez (23) noted, "Discussion of the meaning of these associations needs to take into account the broader context of disability as a whole, rather than focusing solely on musculoskeletal disorders". They also noted that it is "likely that those with lower socioeconomic status carry a double jeopardy; not only is the risk of disease increased, but when it does occur there is also an increased risk of disability" (23). In other words, the construction labourer or the nurse on the orthopedic ward is more likely to injure his or her back than an office worker or doctor, and once injured, it is more difficult for them to return to work.

\section{REDUCING DISABILITY IN CHRONIC PAIN}

Frank et al (32) in a review article on the prevention of disability from work-related low back pain noted that,

\section{"clinical interventions appear by and large to be ineffective in reducing subsequent disability unless they are targeted to people who are disabled and off work after the initial acute phase is over, by which time there is a much higher, and more imminent, risk of chronicity."}

Frank et al noted that care provided to patients off work secondary to LBP for six to eight weeks (the subacute phase) had to be "closely related to the workplace or at least explicitly to the specific goal of 'return to work' (33-35)."

An essential element of the success of subacute interventions involves fully involving the workplace in the management process. Substantial reductions in disability for work-related injuries have been noted by the authors "with a wide range of specific workplace programs, nearly all of which have emphasized offering temporarily modified duties". Workplace intervention 'packages' that have been tested and reported repeatedly include 'comprehensive disability management', in which appropriately modified work is offered according to the injured worker's clinically or functionally assessed physical capacity (36-39), sympathetic communication with the worker and nonadversarial handling of workers' compensation claims (40) and a mixture of approaches (41). Of special note is the repeated theme in these studies that a "supportive workplace response to injury needs to start when the pain is first reported; an individualized and accommodative approach to return to work should follow promptly" (32). The authors contend that this strategy rests on the principle that work-related musculoskeletal injuries have variable healing times and some unfortunately go on to develop chronic painful symptomatology.

The ideal solution to the dilemma of chronic pain and disability is to ensure that every worker has a postgraduate education, an adequate income (amount not defined), works in a highly supportive and flexible environment where physically demanding work is avoidable and is able to pick and choose what tasks they are able to do and at what pace. Unfortunately, these job attributes are generally available only to those with higher education levels, those who are selfemployed or who work for benevolent and enlightened companies. More often, in the real world we must try to manage patients with limited skills and educational levels who have jobs that require substantial physical effort and a workplace environment that is reluctant to make concessions. Our goal should be to view chronic pain disability within the larger context of disability as a whole. Instead, we continue to be diverted by arguments about whether 'tissue healing' has occurred, whether disability is inappropriate within the context of chronic pain or whether one can accurately determine disability based on clinical assessment. Such arguments are distinctly unique to chronic pain. Addressing chronic pain disability in an adversarial and nonsupportive manner, despite the increasing popularity of this approach, has little rationale. It does not appear to result in improved outcomes and only increases suffering among those individuals who are most vulnerable in our society.

\section{CONCLUSIONS}

The studies cited clearly indicate that workplace disability associated with chronic pain disorders is strongly associated with the same socioeconomic factors that are found in other well-accepted disabling disorders, such as stroke, spinal cord injuries and RA. The concept of disability usually requires an initial or continuing medical diagnosis or condition. Socioeconomic factors are fundamental in the ultimate expression of the disability attached to the diagnosis, particularly when discussing return to work issues.

Efforts, therefore, need to be directed towards both better medical management of painful conditions (eg, low back pain) and optimizing socioeconomic interventions. Such efforts should include return to work interventions conducted close to the workplace, involvement of the workplace in return to work management, supportive work and modified work strategies, a nonadversarial attitude and approach, and making the work environment more flexible, particularly for 'high risk' patients. Further research is required to better determine the appropriate or most effective methods of compensating for these socioeconomic factors, as well as better identifying early on the 'risk factors' that lead to chronic pain disability.

\section{REFERENCES}

1. Yelin E, Meenon R, Nevitt M, Epstein W. Work disability in rheumatoid arthritis: effects of disease, social and work factors. Ann Intern Med 1980;93:551-6.

2. Berkowitz M, Johnson WG, Murphy EH. Public Policy Toward Disability. New York: Praeger Publications, 1976:7-21. 
3. Haber LD. Disabling effects of chronic disease and impairment. J Chronic Dis 1971;24:469-87.

4. Luft H. Poverty and Health: Economic Causes and Consequences of Health Problems. Cambridge: Ballinger Publishing Co, 1978:75-108.

5. Nagi SZ. An epidemiology of disability among adults in the United States. Milbank Mem Fund Q Health Soc 1976;54:439-68.

6. Sjogren K. Leisure after stroke. Int Rehabil Med 1982;4:80-7.

7. Black-Schaffer RM, Osber JS. Return to work after stroke: development of a predictive model. Arch Phys Med Rehabil 1990;71:285-90.

8. Coughlan AK, Humphrey M. Presenile stroke: long-term outcome for patients and their families. Rheumatol Rehabil 1982;21:115-22.

9. Black-Schaffer RM, Lemieux L. Vocational outcome after stroke. Topics Stroke Rehab 1994;1:74-86.

10. Bergmann H, Kuthmann M, Von-Ungern-Sternberg A, Weimann V. Medical, education and functional determinants of employment after stroke. J Neural Transmission 1991;33(Suppl):157-61.

11. Howard G, Till JS, Toole JF, Matthews C, Truscott BL. Factors influencing return to work following cerebral infarction. JAMA 1985;253:226-32.

12. Smolkin C, Cohen BS. Socioeconomic factors affecting the vocational success of stroke patients. Arch Phys Med Rehabil 1974;55:269-71.

13. Krause JS, Anson CA. Employment after spinal cord injury: relation to selected participant characteristics. Arch Phys Med Rehabil 1996;77:737-43.

14. Reisine ST, Grady KE, Goodenow C, Fifield J. Work disability among women with rheumatoid arthritis. The relative importance of disease, social, work, and family factors. Arthritis Rheum 1989;32:538-43.

15. Reisine S, McQuillan J, Fifield J. Predictors of work disability in rheumatoid arthritis patients. A five-year followup. Arthritis Rheum 1995;38:1630-7.

16. Leavitt $F$. The physical exertion factor in compensable work injuries. A hidden flaw in previous research. Spine 1992;17:307-10.

17. Yelin EH, Henke CJ, Epstein WV. Work disability among persons with musculoskeletal conditions. Arthritis Rheum 1986;29:1322-33.

18. Teasell RW, Merskey H. Chronic pain disability and the workplace. American Pain Forum 1997;6:228-38(b).

19. Deyo RA, Diehl AK. Psychosocial predictors of disability in patients with low back pain. J Rheumatol 1988;15:1957-64.

20. Leigh JP, Fries JF. Occupation income, and education as independent covariates of arthritis in four national probability samples. Arthritis Rheum 1991;34:984-95.

21. Leigh JP, Fries JF. Predictors of disability in a longitudinal sample of patients with rheumatoid arthritis. Ann Rheum Dis 1992;51:581-7.

22. Pincus T, Callahan LF. Formal education as a marker for increased mortality and morbidity in rheumatoid arthritis. J Chronic Dis 1985;38:973-84.

23. Badley EM, Ibanez D. Socioeconomic risk factors and musculoskeletal disability. J Rheumatol 1994;21:515-22.
24. LaVecchia C, Negri E, Pagano R, Decarli A. Education, prevelance of disease, and frequency of health care utilization. J Epidemiol Community Health 1987;41:161-5.

25. Leigh JP, Fries JF. Education level and rheumatoid arthritis: evidence from five data centers. J Rheumatol 1991;18:24-34.

26. Pincus T, Callahan LF, Burkhauser RV. Most chronic diseases are reported more frequently by individuals with fewer than 12 years of formal education in the age 18-64 United States population. J Chronic Dis 1987;40:865-74.

27. Nagi SZ, Riley LE, Newby LG. A social epidemiology of back pain in a general population. J Chronic Dis 1973;26:769.

28. Reisbord LS, Greenland S. Factors associated with self-reported back-pain prevalence: a population-base study. J Chronic Dis 1985;38:691.

29. Kelsey JL, Golden AL. Occupational and workplace factors associated with low back pain. P. 7. In: Deyo RA, ed. Occupational Medicine: State of the Art Reviews: Back Pain in Workers. Philadelphia: Hanley \& Belfus, 1988.

30. Blaxter M. Health and social class: Evidence on inequality in health from a national survey. Lancet 1987;2:30-3.

31. House JS, Kessler RC, Herzog AR. Age, socioeconomic status, and health. Milbank Q 1990;68:383-411.

32. Frank J, Sinclair S, Hogg-Johnson S. Preventing disability from work-related low-back pain. CMAJ 1998;158:1625-31.

33. Agency for Health Care Policy and Research. Acute low back problems in adults. Clinical Practice Guideline 14, Rockville (MD): US Department of Health and Human Services, 1994.

34. Cohen JE, Goel V, Frank JW, Bombardier C, Peloso P, Guillemin F. Group education interventions for people with low back pain. An overview of the literature. Spine 1994;19:1214-22.

35. Koes BW, van Tulder MV, van der Windt WM, Bouter LM. The efficacy of back schools: a review of randomized clinical trials. J Clin Epidemiol 1994;47:851-62.

36. Yassi A, Tate R, Cooper JE, Snow C, Vallentyne S, Khokhar JB. Early intervention for back-injured nurses at a large Canadian tertiary care hospital: an evaluation of the effectiveness and cost benefits of a two-year pilot project. Occup Med (Lond) 1995;45:209-14.

37. Gice JH, Tompkins K. Return to work in a hospital setting. J Bus Psychol 1989;4:237-43.

38. Ryden LA, Molgaard CA, Bobbitt SL. Benefits of a back care and light duty health promotion program in a hospital setting. J Community Health 1988;13:222-30.

39. Cooper JE, Tate RB, Yassi A, Khokhar J. Effect of an early intervention program on the relationship between subjective pain and disability measures in nurses with low back injury. Spine 1996;21:2329-36.

40. Wood DJ. Design and evaluation of a back injury prevention program within a geriatric hospital. Spine 1987;12:77-82.

41. Battie MC. Minimizing the impact of back pain: workplace strategies. Semin Spine Surg 1992;4:20-8. 


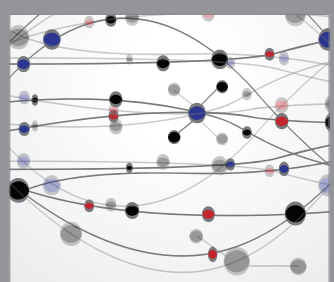

The Scientific World Journal
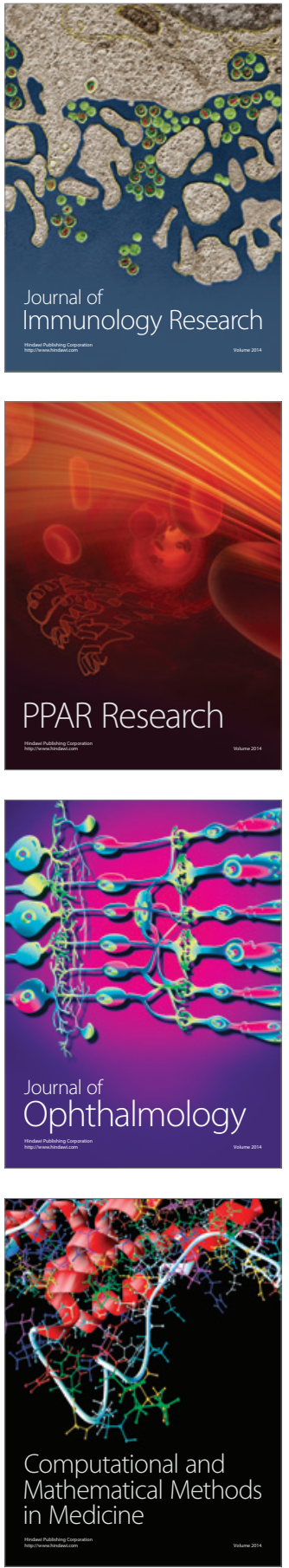

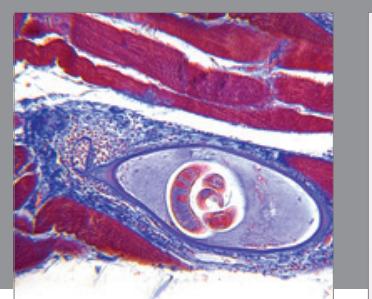

Gastroenterology Research and Practice

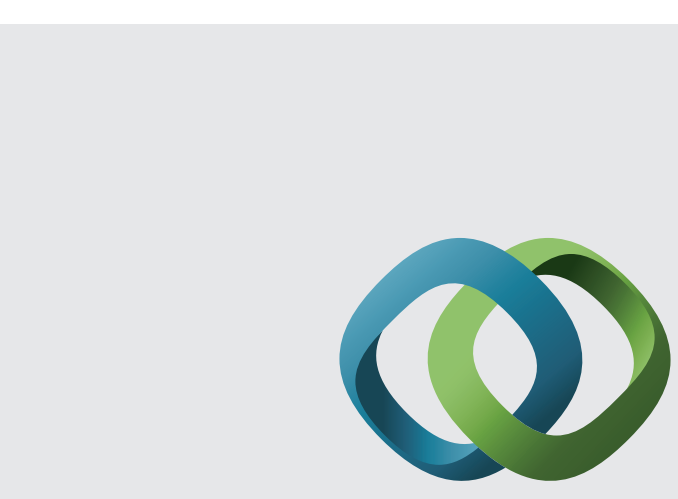

\section{Hindawi}

Submit your manuscripts at

http://www.hindawi.com
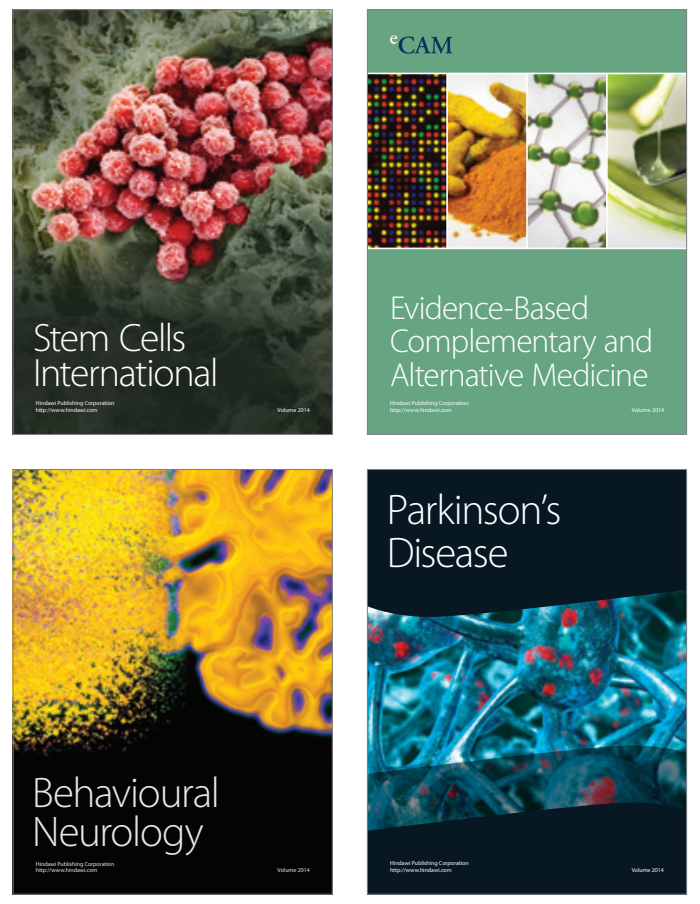
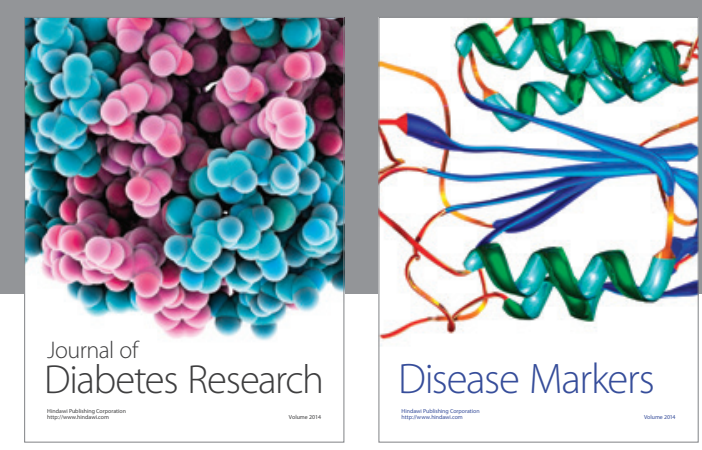

Disease Markers
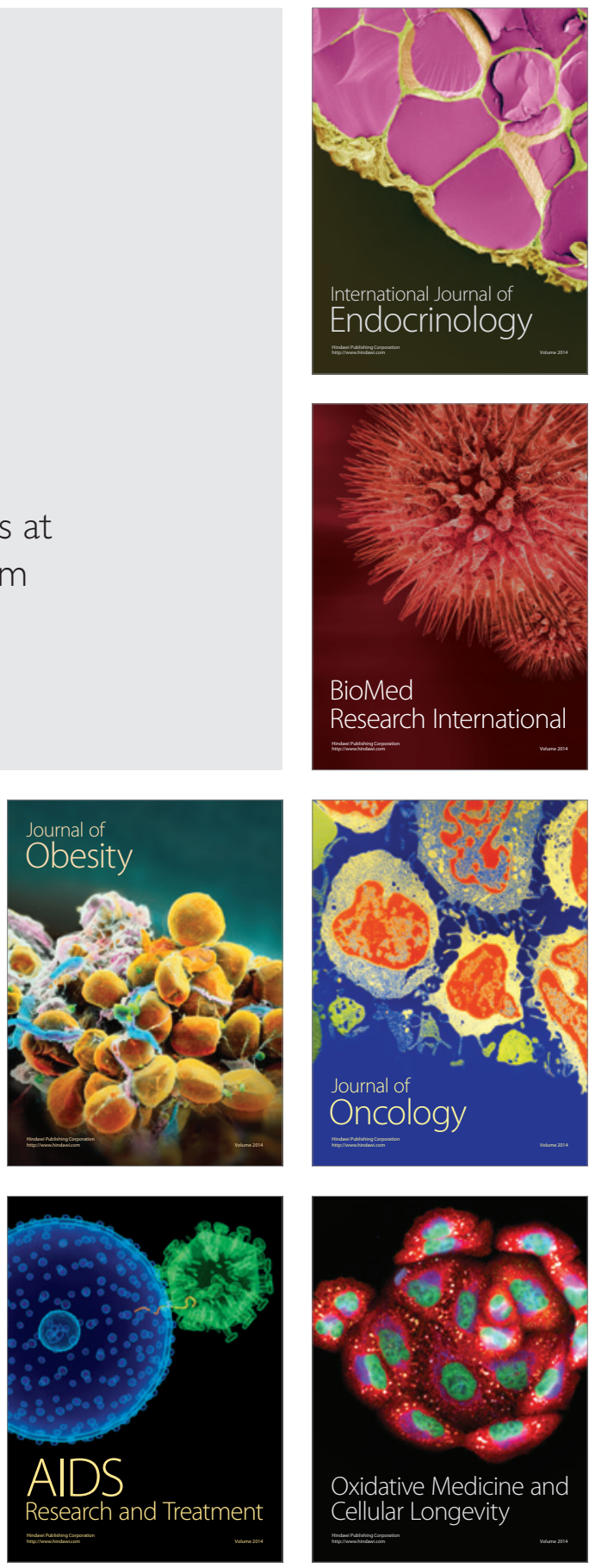